\title{
Researching global environmental politics: trends, gaps, and emerging issues
}

Justin Alger and Peter Dauvergne

This book comes at a time of both promise and peril for the global environment. Environmental problems have never been more prominent on the agendas of states, corporations, and nongovernmental organizations. Each seems to recognize that they have a role to play in staving off ecological crisis, leading to a proliferation of private, public, and hybrid governance mechanisms. The 2015 Paris Agreement on climate change, despite its flaws, for the first time committed all countries to setting targets to reduce greenhouse gas emissions. More and more multinational corporations are voluntarily pledging to pursue zero carbon emissions, zero waste, and fully sustainable supply chains. And increasing numbers of environmental activists are pushing for more ambitious protection of the oceans, forests, and biodiversity.

The global trend is clearly towards doing more to protect the global environment. Yet the various initiatives are obviously not doing nearly enough. By seemingly every metric the global community is falling well short of ending the escalating global environmental crisis. The targets are too modest, the commitments too wavering, and the gains too incremental. Furthermore, a recent wave of antiintellectualism threatens what progress has been made. The world is yet again at a crossroads. Down one road lies a re-envisioning of the relationship between society and environment. Down the other lies the continuity of not doing enough. Scholars of global environmental politics (GEP) have a role to play, as they have in the past, in setting this direction. The persistence of old problems and the emergence of new ones call for a revitalized research agenda for the field.

Research on the relationship between politics and global environmental change has been growing steadily over the past half-century, picking up steam since the early 1990s. Four research trends in the field of global environmental politics stand out over the past 20 years. First, there has been a steady output of analysis on the ecological consequences of the global political economy on issues ranging from global trade and finance to environmental injustice. Second, there has been progressively intricate analysis of the implications for global environmental governance of the thickening layers of government policies, treaties, and international organizations. Third, there has been an increasing analysis of the importance of corporate, nongovernmental, and market-based governance for environmental management. 
And, fourth, there has been a growing focus on the problem of climate change (Dauvergne and Clapp 2016).

The chapters in this book reflect on the contributions and consequences of these research trends to map out significant findings and gaps within the field of global environmental politics. Each chapter strives to identify the most pressing questions and emerging issues for future GEP researchers, especially graduate students looking for topics, theories, and methodologies with a high potential for originality and lasting impact. Together, the chapters engage broadly with three questions within each contributor's area of expertise within global environmental politics:

1. What are the most striking research findings and theoretical insights to date?

2. What are the most significant research gaps, questions, and emerging issues, and what theoretical and methodological approaches would be useful to address them?

3. As a group of scholars, are we asking the right questions given recent environmental trends?

We draw on the chapters in this book to identify gaps and emerging issues to distill an agenda for high-impact and original research in global environmental politics. We divide our overview of this research agenda into five categories: global political economy; international institutions and nonstate governance; ecological crisis; climate politics; and scholar activism and engaged research.

\section{Global political economy}

Are perpetual economic growth and environmental sustainability compatible? For most GEP scholars, the answer is a resounding "no." But the precise nature of the relationship between the global economy and environmental change remains a focal point for research in global environmental politics. Some of it looks at the connection between existing practices-in trade, finance, and more-and environmental impacts (e.g., Conca 2000; Park 2010; Kramarz and Park 2016). Much of this literature remains agnostic about the effects of the global economy on the environment, instead identifying and analyzing trends. But much of it is driven by a normative commitment to a greener economy in which environmental externalities are internalized into global economic institutions. Other research is more critical, noting the inherent incompatibility between unrestrained growth and sustainability (Princen 2005, 2010; Higgs 2014; Wright and Nyberg 2015).

In Chapter 2, J. Samuel Barkin identifies three categories that capture these different approaches with respect to trade: positivist, institutionalist, and critical. As he notes, there is potential for scholars to break down these three silos in trade research, which have unnecessarily limited trade scholarship to date. This prospect for a less rigid research agenda coalesces with new developments in the global trading system. China's enhanced status is altering trade geopolitics, and in some cases 
leading towards protectionist movements. As nationalism begins to reassert influence over trade, as in the US under President Donald Trump since 2017, there is an intriguing potential to study the consequences of what Barkin calls "renationalized capitalisms." As global trade fragments and growth begins to level out, this is an opportune time to revitalize research into trade-environment linkages.

The proliferation of green financing mechanisms since the 1980 os has similarly led to extensive research into the connection between money and environmental management. As Susan Park argues in Chapter 3, the focus of this research has been on how financial mechanisms for environmental governance emerged. But there is a need for systematic analysis of the value of green finance for improving environmental management. As Park notes, the lines are increasingly blurred between public and private financing for environmental governance. Carbon markets, green bonds, and voluntary industry-led green financing are all becoming a more prominent component of global environmental governance. Park's call for more systematic research on green finance identifies an important gap in the field-one in which the broader consequences of green finance directly connect to global and local sustainability.

Beyond trade and finance, there remain several other gaps and emerging issues in GEP scholarship on the global political economy. Supply chains that transcend state boundaries are now core to global capitalism, yet governance of them is thin, and the consequences of corporate self-governance unclear. There is considerable room to expand on the existing research exploring the environmental consequences of supply chains and supply-chain governance, such as the auditing schemes of multinational retailers (LeBaron et al. 2017). The multitude of governance mechanisms for trade, finance, and supply chains have very different implications for the global North and South. As these governance mechanisms evolve, so too does the need for new research into North-South impacts. There is value as well in continuing to probe whether conventional governance of a global capitalist economy of overconsumption can ever slow the escalating ecological crisis (e.g., Maniates 2001; Dauvergne 2016; Clapp 2017; Dauvergne 2018). This was a foundational set of questions in the genesis of the GEP field (Princen et al. 2002), and scholars should not lose sight of this bigger picture, which is all too often a footnote in GEP research.

\section{International institutions and nonstate governance}

The main international response to environmental degradation has been the creation of a complex array of multilateral agreements and institutions to coordinate state action. There is no central body responsible for coordinating environmental governance-no so-called "World Environment Organization" (Biermann 2001). Instead, governance is fragmented and piecemeal, with separate treaties and governing bodies for climate change, biodiversity, trade in endangered species, ozone, transboundary air pollution, and many more. The causes and consequences of these institutions vary, but they tend to share two things in common. First, they are all 
consistent with a model of liberal environmentalism in which economic growth and development are sacred (Bernstein 2001, 2002). Second, they are technocratic, meaning they embody rational, scientific authority and include quantifiable targets for states to meet (Meyer et al. 1997).

GEP scholars have done extensive research to analyze these institutions from a range of perspectives. Some have asked questions similar to those of liberal institutionalist scholars of international relations (IR), looking to better understand how these institutions facilitate cooperation among states (Jinnah 2014). Others are more skeptical of state cooperation, drawing from realist IR scholarship and pointing to an enduring logic of the tragedy of the commons to critique these institutions. Some GEP scholarship on regimes and international institutions explores more specific questions about the interworking of a complex global environmental governance architecture (e.g., Biermann et al. 2009; Selin and VanDeveer 2015). Why do certain environmental issues emerge, and not others? Which states or groups of states are influential in governance processes? How have emerging economies and the global South asserted themselves in global environmental governance in the twenty-first century? The list of questions is extensive, as is the scholarship. Still, the enduring complexity of state governance of environmental issues warrants continued attention from GEP scholars.

There are also areas of global environmental governance that GEP scholars have somewhat neglected to date. Sustainable development is one such area, as Erika Weinthal points out in Chapter 4. The extensive links between environmental governance and sustainable development warrant further attention from the field. Specifically, Weinthal advocates for scholarship that better connects environmental regimes and institutions to local development and vice versa. One avenue for doing so is to take a closer look at the prominence and importance of the UN Sustainable Development Goals (SDGs) for setting the global policy agenda and framing discourse. Weinthal notes that GEP scholars largely neglected the preceding Millennium Development Goals (MDGs), but should not repeat this mistake with the SDGs. The SDGs connect formal multilateral efforts to foster development with efforts to promote sustainability, placing them at the nexus of some of the bigger questions in the field about environmental governance in a capitalist world economy.

Many of the most consequential developments in global environmental governance occur at the international level, with states at the center. How states cooperate to address the world's most pressing environmental issues will remain a central part of GEP scholarship going forward. When countries successfully finalized negotiations for the 2015 Paris Agreement it was met with widespread praise from state leaders and many environmental activists, with some touting it as a "historic agreement." The Paris Agreement was indeed monumental in that it was the first multilateral agreement to commit all countries to mitigating climate change. But the agreement falls short of the aggressive commitments needed to overhaul the carbon economy and meaningfully slow climate change. GEP scholarship on regimes and 
institutions is critical to understanding the political causes and consequences of agreements such as the Paris Agreement (Keohane and Oppenheimer 2016; Young 2016). How environmental regimes and institutions emerge and evolve, how they mold state (and other stakeholder) behavior, and how they shape and are shaped by local realities will remain foundational questions in GEP scholarship.

Global environmental politics scholars have also been at the vanguard of a broader trend in international relations to incorporate nonstate actors into research and analysis (e.g., Betsill and Corell 2001; Cashore et al. 2004; Vogel 2005; Bäckstrand 2008; Falkner 2008). Corporations and nonprofit NGOs feature prominently in the literature. Corporations of course play a large role in driving overconsumption and are among the biggest polluters, but they have also increasingly engaged in voluntary private governance efforts to promote more sustainable, environmentally friendly business practices (Vogel 2010; Dauvergne and Lister 2013; van der Ven 2014; Bloomfield 2017a, 2017b). NGOs engage in a wide range of activities, such as lobbying and pressuring states, advocating for new solutions to environmental problems, rallying public support, and in some rare cases even financing certain aspects of government policy implementation. How these groups operate and are able to influence and shape governance to their liking is a fundamental part of GEP scholarship.

Sustainability certification schemes were among the earliest and most prominent forms of private environmental governance. GEP scholars have devoted considerable attention to such schemes for forestry, seafood, and palm oil, to name the most well known. As set out in Chapter 5, Lars H. Gulbrandsen now sees a need for a more expansive set of research questions and approaches for scholars of sustainability certification programs. Most scholarship in this area has employed a single case study methodology to answer questions about how a given scheme emerged and how it changed management and behavior. Interdisciplinary research that employs comparative and quantitative methodologies could help expand on what has to date been an extensively researched but somewhat narrow subfield of GEP. As Gulbrandsen puts it, more research into the long-term consequences of these schemes for environmental policy and governance generally is needed.

Finding cohesion in the array of public, private, and hybrid governance mechanisms for environmental problems remains a challenge for both scholars and practitioners. Fragmentation of environmental governance remains a common theme across most environmental problems (Biermann et al. 2009). In Chapter 6, Timothy Adivilah Balag'kutu, Jason J. McSparren, and Stacy D. VanDeveer argue this is the case in the governance of extractives, most notably mining and minerals. Transparency of mining and minerals governance is poor, facilitating a climate in which mining companies are able to exert excessive influence over industry rules. This influence has allowed mining companies to perpetuate exploitative practices, particularly in the global South. Governance of some of the most pressing problems in the sector remains weak as a result, with issues ranging from the ongoing production of conflict minerals to the release of mercury into the environment seeing limited progress. 
The importance of nonstate environmental governance is continuing to grow. The centrality of corporations and NGOs to environmental issues means GEP scholars are likely to remain at the forefront of IR scholarship on nonstate governance (e.g., Wapner 1996, 2002; Bloomfield 2017a). The growing role of cities in global environmental governance is also extending the research to include substate actors (Bulkeley and Betsill 2013; Gordon and Acuto 2015; Simon 2016; Johnson 2018). Some fairly big and vital questions remain in the field. The effectiveness of voluntary corporate sustainability commitments is a crucial question for understanding not just how these commitments might shape corporate behavior but how they shape governance generally. Do they lead to more sustainable practices, or do they distract from efforts towards more wholesale change? The effectiveness of activism and NGO partnerships is understudied, particularly given the importance of activists and environmental groups to advancing environmental agendas (Dauvergne and LeBaron 2014; Allan and Hadden 2017; Dauvergne 2017). Why do some activist campaigns resonate and others falter? Similarly, under what conditions are NGO partnerships able to influence government environmental policy? Emerging scholars can feel encouraged that there is a pressing need for more research into such big questions.

\section{Ecological crisis}

The preceding sections focus on global environmental governance broadly defined, with lessons and analysis that apply across a breadth of environmental issues. But much GEP research is issue specific, providing detailed analysis of the politics of a range of pressing environmental problems, including climate change, biodiversity loss, persistent organic pollutants, the waste crisis, and many more too numerous to list here. Climate change dominates GEP research and public discourse because of the immensity of governance challenges and the severe consequences of failure. For this reason, we devote three chapters of this book (Chapters 10-12) to climate politics as an environmental issue area. Before turning to climate, however, we look at research trends and gaps in other prominent environmental problems.

Some issues have already received considerable attention from GEP scholars. Research on food and agriculture, biofuels, and deforestation is extensive (e.g., Clapp 2001, 2012; Neville 2015; Clapp 2016; Kashwan 2017; Clapp and Isakson 2018). So is the scholarship on water, energy, and mining (e.g., Conca 2006; Conca and Weinthal 2018; Gamu and Dauvergne 2018; Kelsey and Meckling 2018). And so is the research on fishing, endangered species, whaling, ozone, chemicals, waste, and automobiles (e.g., O'Neill 2000; Paterson 2007; Epstein 2008; Barkin and DeSombre 2013). As with any field of scholarship, there is always room for new and innovative ways of conducting research into these issues. In some cases, new developments or insights may open the door for expanded analysis. For example, while forest degradation has long been a focus of GEP scholarship, some attention has shifted towards palm oil as the leading cause of deforestation, especially in Indonesia and Malaysia. In part owing to the ubiquity of palm oil in consumer 
goods, governing palm oil has proven challenging, with private certification schemes having negligible impact on deforestation rates. A recent influx of palm oil research in leading journals indicates that GEP scholars have been responsive to new developments, eager to explore old issues in newer ways. As ecological threats multiply and as governments respond to them, the politics of them can change, creating new avenues for scholars to explore.

Kate O'Neill's analysis, in Chapter 7, of the waste crisis is a telling example of how shifting political economies are significantly altering the political dynamics of an environmental issue. China has long been the recipient of waste produced in the West, seemingly reflecting a broader trend of countries in the global North offloading environmental impacts onto countries in the global South (Dauvergne 2008). But O'Neill notes that China is by no means a victim, instead using imports of scrap to fuel its growth while securing itself a powerful position in the global political economy of waste. The world's richest countries no longer have enough capacity to process all of their own waste, so they now face a potential waste crisis as China restricts scrap imports. The balance of power is shifting in the global economy, with states such as China now more prominent, and GEP research will need to follow suit. As O'Neill puts it with respect to waste, the traditional narrative of the global North as perpetrator and the global South as victim is now too simplistic for at least some environmental issues.

The environmental politics of food have similarly become increasingly complex as transnational actors continue to dominate food systems. In Chapter 8, Jennifer Clapp and Phoebe Stephens point to a constantly changing global food landscape. A shift towards "digital farming," the need for greater investment in local market systems, and the paradox of high global obesity and hunger levels, they argue, are all research imperatives if the global community is to move towards food sustainability. Clapp and Stephens note not just fragmented food governance, but a dearth of governing institutions. This governance gap poses a challenge to GEP researchers as they work towards a better understanding of global food system-environment dynamics. As with many environmental issues, research into the environmental politics of food generally requires interdisciplinarity if results are to be problem focused and policy relevant.

There are also a number of emerging environmental issues that are ripe for GEP research, including plastic pollution, pelagic ocean protection, pesticides, coral reefs, fracking, nanotechnology, geoengineering, and outer space pollution. Relative to the environmental issues listed above, GEP scholars have devoted less attention to challenges in these areas, despite their importance for planetary stability. For example, the alarming amount of plastic in our water systems warrants more attention. Trace amounts of plastic are in the water from nearly every tap in the world, regardless of wealth or geographic location (Tyree and Morrison 2017). The environmental consequences of this trend are potentially dire, yet so far there has been little social science research into the politics of plastic contamination, albeit with some notable exceptions (e.g., Clapp and Swanston 2009). On the more 
optimistic side, governments have recently scaled up their efforts to protect pelagic (open ocean) ecosystems - one of the least protected ecosystems on the planet (Alger and Dauvergne 2017a, 2017b). These efforts have opened the door for better protection of the high seas (international waters), with multilateral efforts for ocean governance set to expand in the coming years. GEP scholarship in this area remains limited given the importance of healthy marine ecosystems for other environmental issues, including climate change.

In Chapter 9, Elizabeth R. DeSombre notes the significant room for innovative scholarship in ocean governance, identifying some key ways in which GEP scholars can expand its scope. Multilateral efforts to protect the high seas, the linkages between ocean and climate governance, and the governance of previously neglected issues, such as seabed mining or shipping, all warrant further investigation. DeSombre also calls on GEP scholars to apply more critical approaches to ocean governance. Existing governance mechanisms tend to legitimize the extractive and polluting activities that degrade the oceans (Lobo and Jacques 2017). As oceans decline at an alarming rate and governments respond with new measures, the need for diverse and innovative research into ocean politics grows.

There is a seemingly ever-expanding list of threats to the planet. Waste, food sustainability, and ocean governance are just a few of many environmental issues for which there is room for an expanded research agenda. And the need for new issue-centered research in GEP will surely continue to grow, as ecological threats multiply in number and magnitude, and as governments and communities struggle to contain them.

\section{Climate politics}

Climate change is the greatest environmental threat facing the planet, and GEP scholars have naturally devoted extensive time and energy to better understanding its politics (e.g., Hoffmann 2011; Bulkeley et al. 2014; Bulkeley and Newell 2015). From 2001 to 2015, over half of the articles in the journal Global Environmental Politics that provided detailed analysis of an environmental issue focused on climate (Dauvergne and Clapp 2016). Climate change has, understandably, dominated GEP scholarship over the past two decades. The politics of climate change is, therefore, a somewhat crowded field. But climate change and governance mechanisms to address it are dynamic, leading to an ever-evolving list of questions and challenges for GEP scholars to explore.

As Sonja Klinsky argues in Chapter 10, there are a multitude of analytical lenses through which scholars can approach climate change research across many disciplines. Studying the politics of climate change, however, requires researchers to focus on climate change itself rather than treat it as a case study of some other broader phenomenon. In doing so, she calls on GEP scholars to engage in climate research that focuses on sub-issues of climate change rather than generic 
climate change. More focused climate research may help emerging scholars carve out a place in a crowded field while simultaneously enhancing its policy relevance. Klinsky also calls for research that is "non-naïve" to climate change as a politically contentious subject with a powerful cultural element and deep-seated concerns about inequality and injustice (Schlosberg 2007; Klinsky et al. 2017; Klinsky and Brankovic 2018). Put simply, scholars can and should do more to engage with the darker side of climate politics in addition to more common analyses of various governance mechanisms.

This call for non-naïve climate research in part requires reflection on what constitutes climate governance. In Chapter 11, Harriet Bulkeley, Mark Cooper, and Johannes Stripple suggest that we can advance climate research by rejecting that climate governance represents a coherent whole, instead focusing our efforts on examining the specifics of everyday forms of climate governance. Power relations within cultural, social, and material settings make up the component parts of what we broadly call climate governance, and are essential to understanding the causes and consequences of climate change. GEP scholars have devoted considerable analysis to multilateral agreements and carbon pricing schemes, but less to the intrinsic power in everyday life across a multitude of sites, from boardrooms to shopping malls to tropical forests. One possible avenue for future climate change research is to explore the potential for a "deeper" analysis that explores specific and untraditional sites of power as distinct rather than just byproducts of the broader climate regime.

And yet there is a pressing need for GEP scholars to reevaluate the climate governance regime, traditionally understood. In Chapter 12, Felicia Peck laments that climate scholarship tends to accept the climate regime as it is. She challenges the value of technocratic and econometric understandings of the causes, consequences, and solutions to climate change. Climate scholars have gone too far down the road of divorcing their social scientific analyses of climate from on-the-ground environmental impacts. As Peck puts it, the material element of an environmental issue is of great importance to its politics. For climate research, this means placing more emphasis on carbon itself rather than the mechanisms and policy tools designed to mitigate it. A focus on carbon-as an atomic element and a word with discursive power-enables scholars to ask bigger questions about the desirability of the mechanisms that much climate research has examined to date.

Despite a crowded field with extensive GEP scholarship to date, there is still considerable room for innovative work on the politics of climate change. New governance mechanisms and policy tools will emerge to address climate change that will warrant expanding on some of the more traditional research questions and practices that characterize GEP scholarship on climate to date. But climate research in GEP will increasingly need to push the boundaries of what has become mainstream. Despite progress in leveling out emissions in certain countries, the world is still well behind pace to prevent the worst consequences of climate change. Climate scholars have not been asking the wrong questions, but perhaps asking similar questions too 
often. The global failure to meaningfully slow catastrophic climate change provides the impetus for climate scholars to reimagine and reinvigorate the field.

\section{Conclusion: scholar activism and engaged research}

In this chapter, we have compartmentalized GEP scholarship into sections that broadly reflect how scholars have approached their research into the politics of environmental change. Many focus on the structures that shape how humanity interacts with the natural world, be it through a study of the global economy, of international regimes and institutions, or of the growing influence of nonstate actors. Others organize their research around a specific environmental issue in efforts to better understand its unique political, economic, and social challenges. In practice, much GEP scholarship tends to do both simultaneously. It works to advance theoretical knowledge of global environmental governance while exploring its implications for climate change, biodiversity loss, or the myriad other threats to the environment.

Two common themes emerge in this effort to propose a research agenda for the field across these broad categories of GEP scholarship. The first, echoed by many scholars in this volume, is the need for GEP scholars to connect social phenomena more closely to environmental impacts and change. There is a perhaps understandable tendency in the field to divorce the social from the ecological. It stems in part from the immense difficulty in measuring ecological impacts and change, especially for social scientists without the training or resources to do so firsthand. More interdisciplinary research could help. But this tendency also arises out of the types of questions that GEP scholars ask. All too often GEP scholarship gets lost in the weeds of institutions and governance mechanisms without due analysis of what they all mean for environmental change. That is not to say this research isn't valuable. It is. But, in a field in which the overwhelming majority of scholars share a normative commitment to protecting the planet, we can perhaps do more. A reinvigorated GEP research agenda needs to better connect social phenomena to environmental consequences.

A second theme is the tendency of GEP scholars to ask the same or similar questions too often. We only need to look at the extensive scholarship on, for example, the emergence of the Forest Stewardship Council (FSC) or the functioning of carbon markets (to unfairly single out a couple). Pioneers of research in these areas have noted this trend themselves (including in this volume), and are calling for emerging scholars to be more innovative and expansive in their research questions. The chapters in this book offer some guidance on how best to proceed. Emerging GEP scholars are in a fortunate position given just how young the field is. Older disciplines often require newer scholars to be modest in their ambitions-to find a small niche within an extensively studied area. The novelty of the GEP field and the immensity of the challenges it seeks to address mean that there is still plenty of room to ask big questions (e.g., Burke et al. 2016; Falkner and Buzan 2017). 
As Kate J. Neville and Matthew Hoffmann so persuasively argue in Chapter 14, scholars of global environmental politics are at once scholars and activists. As the global environmental crisis continues to escalate, these two roles inevitably become more intertwined. The GEP field is innately normative in the sense of caring about the environment and wanting to shift politics towards greater sustainability. In a world characterized not only by environmental crisis but by growing skepticism of the role and value of experts, this scholar-activist path is an increasingly difficult one to navigate. Neville and Hoffmann call for GEP scholars to be upfront with their normative position, for the sake of research transparency and to improve trust between scholars and the rest of society. In Chapter 13, J. Timmons Roberts cautions that GEP scholarship also needs to be "engaged." Put simply, solutions to environmental problems are only viable if they are just, properly addressing equity issues in environmental politics. The call for more emphasis on environmental impacts and change should not be blind to the social consequences of environmental policy, particularly for marginalized groups. Roberts sees the Paris Agreement on climate change as a failure in this regard, calling on GEP scholars to take on a bolder, more ambitious role in directly connecting their research to the work of international organizations, governments, and a range of nonstate actors.

There is a sense of despair that comes with being a global environmental politics scholar in a world undergoing ecological crisis, but it is at the same time an exciting time to be in this field. The stakes are high, there is global momentum across a host of environmental issues, and there is a need for new and innovative research asking big questions about politics and the environment. The chapters in this book suggest some ways forward, but emerging GEP scholars will dictate the trajectory of the field as they begin to answer some of these questions, and devise their own. The good news is that they have no shortage of options.

\section{References}

Alger, Justin, and Peter Dauvergne. 2017a. The Global Norm of Large Marine Protected Areas: Explaining Variable Adoption and Implementation. Environmental Policy and Governance 27 (4): 298-310.

Alger, Justin, and Peter Dauvergne. 2017b. The Politics of Pacific Ocean Conservation: Lessons from the Pitcairn Islands Marine Reserve. Pacific Affairs 90 (1): 29-50.

Allan, Jen Iris, and Jennifer Hadden. 2017. Exploring the Framing Power of NGOs in Global Climate Politics. Environmental Politics 26 (4): 600-620.

Bäckstrand, Karin. 2008. Accountability of Networked Climate Governance: The Rise of Transnational Climate Partnerships. Global Environmental Politics 8 (3): 74-102.

Barkin, J. Samuel, and Elizabeth R. DeSombre. 2013. Saving Global Fisheries: Reducing Fishing Capacity to Promote Sustainability. Cambridge, MA: MIT Press.

Bernstein, Steven. 2001. The Compromise of Liberal Environmentalism. New York: Columbia University Press.

Bernstein, Steven. 2002. Liberal Environmentalism and Global Environmental Governance. Global Environmental Politics 2 (3): 1-16.

Betsill, Michele M., and Elisabeth Corell. 2001. NGO Influence in International Environmental Negotiations: A Framework for Analysis. Global Environmental Politics 1 (4): 65-85. 
Biermann, Frank. 2001. The Emerging Debate on the Need for a World Environment Organization. Global Environmental Politics 1 (1): 45-55.

Biermann, Frank, Philipp Pattberg, Harro van Asselt, and Fariborz Zelli. 2009. The Fragmentation of Global Governance Architectures: A Framework for Analysis. Global Environmental Politics 9 (4): 14-40.

Bloomfield, Michael J. 2017a. Dirty Gold: How Activism Transformed the Jewelry Industry. Cambridge, MA: MIT Press.

Bloomfield, Michael J. 2017b. Global Production Networks and Activism: Can Activists Change Mining Practices by Targeting Brands? New Political Economy 22 (6): 727-742.

Bulkeley, Harriet, and Michele M. Betsill. 2013. Revisiting the Urban Politics of Climate Change. Environmental Politics 22 (1): 136-154.

Bulkeley, Harriet, and Peter Newell. 2015. Governing Climate Change, 2nd Edition. Abingdon: Routledge.

Bulkeley, Harriet, Liliana B. Andonova, Michele M. Betsill, Daniel Compagnon, Thomas Hale, Matthew J. Hoffmann, Peter Newell, Matthew Paterson, Charles Roger, and Stacy D. VanDeveer. 2014. Transnational Climate Change Governance. Cambridge: Cambridge University Press.

Burke, Anthony, Stefanie Fishel, Audra Mitchell, Simon Dalby, and Daniel J. Levine. 2016. Planet Politics: A Manifesto from the End of IR. Millennium: Journal of International Studies 44 (3): 499-523.

Cashore, Benjamin, Graeme Auld, and Deanna Newsom. 2004. Governing through Markets: Forest Certification and the Emergence of Non-state Authority. New Haven, CT: Yale University Press.

Clapp, Jennifer. 2001. Toxic Exports: The Transfer of Hazardous Wastes from Rich to Poor Countries. Ithaca, NY: Cornell University Press.

Clapp, Jennifer. 2012. Hunger in the Balance: The New Politics of International Food Aid. Ithaca, NY: Cornell University Press.

Clapp, Jennifer. 2016. Food, 2nd Edition. Cambridge: Polity.

Clapp, Jennifer. 2017. The Trade-ification of the Food Sustainability Agenda. Journal of Peasant Studies 44 (20): 335-353.

Clapp, Jennifer, and S. Ryan Isakson. 2018. Speculative Harvests: Financialization, Food, and Agriculture. Black Point, NS: Fernwood Press.

Clapp, Jennifer, and Linda Swanston. 2009. Doing Away with Plastic Shopping Bags: Explaining International Patterns of Norm Adoption and Policy Diffusion. Environmental Politics 18 (3):315-332.

Conca, Ken. 20oo. The WTO and the Undermining of Global Environmental Governance. Review of International Political Economy 7 (3): 484-494.

Conca, Ken. 2006. Governing Water: Contentious Transnational Politics and Global Institution Building. Cambridge, MA: MIT Press.

Conca, Ken, and Erika Weinthal, eds. 2018. The Oxford Handbook of Water Politics and Policy. Oxford: Oxford University Press.

Dauvergne, Peter. 2008. The Shadows of Consumption: Consequences for the Global Environment. Cambridge, MA: MIT Press.

Dauvergne, Peter. 2016. Environmentalism of the Rich. Cambridge, MA: MIT Press.

Dauvergne, Peter. 2017. Is the Power of Brand-Focused Activism Rising? The Case of Tropical Deforestation. Journal of Environment and Development 22 (4): 391-410.

Dauvergne, Peter. 2018. Will Big Business Destroy Our Planet? Cambridge: Polity.

Dauvergne, Peter, and Jennifer Clapp. 2016. Researching Global Environmental Politics in the 21st Century. Global Environmental Politics 16 (1): 1-12.

Dauvergne, Peter, and Genevieve LeBaron. 2014. Protest Inc.: The Corporatization of Activism. Cambridge: Polity.

Dauvergne, Peter, and Jane Lister. 2013. Eco-business: A Big-Brand Takeover of Sustainability. Cambridge, MA: MIT Press.

Epstein, Charlotte. 2008. The Power of Words in International Relations: Birth of an Anti-whaling Discourse. Cambridge, MA: MIT Press. 
Falkner, Robert. 2008. Business Power and Conflict in International Environmental Politics. Basingstoke: Palgrave Macmillan.

Falkner, Robert, and Barry Buzan. 2017. The Emergence of Environmental Stewardship as a Primary Institution of Global International Society. European Journal of International Relations. First published online at: https://doi.org/10.1177/1354066117741948.

Gamu, Jonathan K., and Peter Dauvergne. 2018. The Slow Violence of Corporate Social Responsibility: The Case of Mining in Peru. Third World Quarterly. First published online at: https://doi.org/10.108 o/01436597.2018.1432349.

Gordon, David J., and Michele Acuto. 2015. If Cities Are the Solution, What Are the Problems? The Promise and Perils of Urban Climate Leadership. In The Urban Climate Challenge: Rethinking the Role of Cities in the Global Climate Regime, edited by Craig Johnson, Noah Toly, and Heike Schroeder, 63-81. New York: Routledge.

Higgs, Kerryn. 2014. Collision Course: Endless Growth on a Finite Planet. Cambridge, MA: MIT Press.

Hoffmann, Matthew J. 2011. Climate Governance at the Crossroads: Experimenting with a Global Response after Kyoto. Oxford: Oxford University Press.

Jinnah, Sikina. 2014. Post-treaty Politics: Secretariat Influence in Global Environmental Governance. Cambridge, MA: MIT Press.

Johnson, Craig A. 2018. The Power of Cities in Global Climate Politics: Saviours, Supplicants or Agents of Change? Cities and the Global Politics of the Environment. London: Palgrave Macmillan.

Kashwan, Prakash. 2017. Democracy in the Woods: Environmental Conservation and Social Justice in India, Tanzania, and Mexico. New York: Oxford University Press.

Kelsey, Nina, and Jonas Meckling. 2018. Who Wins in Renewable Energy? Evidence from Europe and the United States. Energy Research and Social Science 37: 65-73.

Keohane, Robert O., and Michael Oppenheimer. 2016. Paris: Beyond the Climate Dead End through Pledge and Review? Politics and Governance 4 (3): 142-151.

Klinsky, Sonja, and Jasmina Brankovic. 2018. The Global Climate Regime and Transitional Justice. New York: Routledge.

Klinsky, Sonja, Timmons Roberts, Saleemul Huq, Chukwumerije Okereke, Peter Newell, Peter Dauvergne, Karen O’Brien, Heike Schroeder, Petra Tschakert, Jennifer Clapp, Margaret Keck, Frank Biermann, Diana Liverman, Joyeeta Gupta, Atiq Rahman, Dirk Messner, David Pellow, and Steffen Bauer. 2017. Why Equity Is Fundamental in Climate Change Policy Research. Global Environmental Change 44: 170-173.

Kramarz, Teresa, and Susan Park. 2016. Accountability in Global Environmental Governance: A Meaningful Tool for Action? Global Environmental Politics 16 (2): 1-21.

LeBaron, Genevieve, Jane Lister, and Peter Dauvergne. 2017. Governing Global Supply Chain Sustainability through the Ethical Audit Regime. Globalizations 14 (6): 958-975.

Lobo, Rafaella, and Peter Jacques. 2017. SOFIA'S Choices: Discourses, Values, and Norms of the World Ocean Regime. Marine Policy 78: 26-33.

Maniates, Michael F. 2001. Individualization: Plant a Tree, Buy a Bike, Save the World? Global Environmental Politics 1 (3): 31-52.

Meyer, John W., David John Frank, Ann Hironaka, Evan Schofer, and Nancy Brandon Tuma. 1997. The Structuring of a World Environmental Regime, 1870-1990. International Organization 51 (4): 623-651.

Neville, Kate J. 2015. The Contentious Political Economy of Biofuels. Global Environmental Politics 15 (1): 21-40.

O'Neill, Kate. 200o. Waste Trading among Rich Nations: Building a New Theory of Environmental Regulation. Cambridge, MA: MIT Press.

Park, Susan. 2010. World Bank Group Interactions with Environmentalists: Changing International Organisation Identities. Manchester: Manchester University Press.

Paterson, Matthew. 2007. Automobile Politics: Ecology and Cultural Political Economy. Cambridge: Cambridge University Press. 
Princen, Thomas. 2005. The Logic of Sufficiency. Cambridge, MA: MIT Press.

Princen, Thomas. 2010. Treading Softly: Paths to Ecological Order. Cambridge, MA: MIT Press.

Princen, Thomas, Michael Maniates, and Ken Conca, eds. 2002. Confronting Consumption. Cambridge, MA: MIT Press.

Schlosberg, David. 2007. Defining Environmental Justice: Theories, Movements, and Nature. Oxford: Oxford University Press.

Selin, Henrik, and Stacy D. VanDeveer. 2015. European Union and Environmental Governance. New York: Routledge.

Simon, Curtis. 2016. Cities and Global Governance: State Failure or a New Global Order? Millennium: Journal of International Studies 44 (3): 455-477.

Tyree, Chris, and Dan Morrison. 2017. Invisibles: The Plastic inside Us. Available online at: https:// orbmedia.org/stories/Invisibles_plastics, last accessed January 23, 2018.

Ven, Hamish van der. 2014. Socializing the C-Suite: Why Some Big-Box Retailers Are "Greener" than Others. Business and Politics 16 (1): 31-63.

Vogel, David. 2005. The Market for Virtue: The Potential and Limits of Corporate Social Responsibility. Washington, DC: Brookings Institution Press.

Vogel, David. 2010. The Private Regulation of Global Corporate Conduct: Achievements and Limitations. Business and Society 49 (1): 68-87.

Wapner, Paul. 1996. Environmental Activism and World Civic Politics. Albany: State University of New York Press.

Wapner, Paul. 2002. Horizontal Politics: Transnational Environmental Activism and Global Cultural Change. Global Environmental Politics 2 (2): 37-62.

Wright, Christopher, and Daniel Nyberg. 2015. Climate Change, Capitalism, and Corporations: Processes of Creative Self-Destruction. Cambridge: Cambridge University Press.

Young, Oran R. 2016. The Paris Agreement: Destined to Succeed or Doomed to Fail? Politics and Governance 4 (3): 124-132. 